\title{
TOWARDS SUSTAINABILITY THROUGH GREEN, LEAN AND SIX SIGMA INTEGRATION AT SERVICE INDUSTRY: REVIEW AND FRAMEWORK
}

\author{
Rodrigo CAIADO $^{1}$ (D), Daniel NASCIMENTO ${ }^{1,2}$, Osvaldo QUELHAS $^{1}$, \\ Guilherme TORTORELLA ${ }^{3}$, Luis RANGEL ${ }^{1}$ \\ ${ }^{1}$ Sustainable Management Systems Department, Federal Fluminense University, \\ Rua Passo da Pátria, 156, 24210-240, Niterói, Brazil
}

${ }^{2}$ Civil and Environmental Engineering Department, Pontifical Catholic University of Rio de Janeiro, Rua Marquês de São Vicente, 225, 22430-060, Rio de Janeiro, Brazil

${ }^{3}$ Department of Production and Systems Engineering, Federal University of Santa Catarina, Campus Reitor João David Ferreira Lima, 88040-900, Florianópolis, Brazil

Received 27 September 2017; accepted 24 March 2018

\begin{abstract}
In the last decades, sustainable development has increasingly gained importance to service industry and the integration between Green, Lean and Six Sigma approaches in service systems is necessary in order to balance the need for operational efficiency with environmental commitment and social fairness. Because of that, the purpose of this paper is to critically review the Lean and Lean Six Sigma (LSS) methodologies and highlight their importance to achieve sustainable services. To do this, a systematic literature review of the subjects under investigation was conducted. The study has two major contributions. First, it is one of the first researches that examine the compatibility and divergences of Green, Lean and Six Sigma concepts and implications regarding its sustainable implementation in service industry. Second, it provides a holistic Green LSS framework attempting to help practitioners to find ways of institutionalizing it in numerous kinds of services, by pointing out nine critical factors for its implementation, such as continuous customer satisfaction, ethical relations and regulatory compliance, focus on knowledge management and human behaviors, and effective Jidoka automation. The proposed framework indicates new paradigms and pathways to achieve the balance in technical, economic, social and environmental priorities in services.
\end{abstract}

Keywords: Lean thinking, Lean Six Sigma (LSS), organizational sustainability, sustainable development, service industry, systematic literature review (SLR).

JEL Classification: L80, O14, Q01, Q55.

*Corresponding author. E-mail: rodrigoggcaiado@gmail.com 


\section{Introduction}

Sustainable concerns have increasingly gained importance in societies and economies discussions over the last decades. In addition to, in the post-modern era there is a growing pressure to improve quality, efficiency, effectiveness and sustainability of services, an industry which accounts for more than $50 \%$ of gross domestic product in the big economies around the world.

In the last decade, academics and practitioners have extensively cited the benefits of Lean implementation to the service industry. Most of these studies were applied in healthcare (e.g. laboratories chain, hospitals, nursing and surgery), insurance companies, software giants to educational institute, within both public and private sectors.

Nowadays, although the integration between Lean Thinking and Six Sigma become more popular among the manufacturing industry, the Lean Six Sigma (LSS) practices are progressively becoming widespread in studies about service. The LSS incorporates the principles of speed and immediate action of Lean with the vision of Six Sigma of quality without defect and reduction of the impact of the variation in the times of queue; it attacks the hidden costs of complexity and is a mechanism that seeks the engagement of all for joint reach and without trade-offs of quality, speed, and cost (George, 2003). However, the service industry still has few studied about the LSS (Albliwi, Antony, \& Lim, 2015) and even less regarding the sustainable development (SD) (Garza-Reyes, 2015b; Hallam \& Contreras, 2016; Cherrafi, Elfezazi, Chiarini, Mokhlis, \& Benhida, 2016; Chugani, Kumar, Garza-Reyes, Rocha-Lona, \& Upadhyay, 2017). Thus, there is lack of studies about ways of achieve the SD in services through LSS. In addition, while there are separate streams of research on Lean, sustainability, and services, the intersection of these three strategic areas has not been extensively addressed in the past.

The purpose of this paper is to critically review the Lean and LSS methodologies and highlight their importance to achieve sustainable development in service industry. To do this, a systematic literature review (SLR) of the subjects under investigation was conducted in order to locate the relevant existing studies and to evaluate and synthesize their respective contributions (Caiado, Dias, Mattos, Quelhas, \& Leal Filho, 2017). This review explores the following questions:

1) What are the compatibilities and divergences between Green and Lean /LSS in service industry?

2) What are the challenges and enablers to align Lean/LSS with organizational sustainability?

3) What are the main implications of Lean and LSS for achieving green services?

The research has responded to the growing need of studies about Lean and sustainability in service industry (Cherrafi, Elfezazi, Chiarini, Mokhlis, \& Benhida, 2016) and the lack of systematic reviews about LSS (Albliwi et al., 2015). It also aims to bridge the knowledge gap on the integration of Lean Six Sigma and Green practices. Given the emerging gaps, this article has two major contributions. Firstly, to expand the existing body of knowledge on how Lean Thinking and Lean Six Sigma can foster sustainability outcomes, focusing on the service industry. Thus, it delves deeper into the compatibilities, divergences between Lean/ LSS and Green, the challenges and enablers to integrate these approaches, which seems to be 
neglected by the current literature and explores the related implications for the configuration of these interrelationships. Secondly, to provide a holistic framework integrating Lean, Six Sigma and Green approaches that can be investigated in many different sectors, attempting to find ways of institutionalising Green LSS philosophy in any service. Furthermore, it is expected that this framework serves as a guide for managers, leaders and decision makers pointing out a path to the alignment of these approaches. The main findings of the paper have implications from both theoretical and the managerial point of view, providing a better panorama to understand the present status of Lean/LSS methods towards greener services.

The study is organized as follows. In Section 1, there is a background of Lean, Six Sigma and sustainability. The Section 2 presents methodological procedures employed in the systematic literature review. Then the results from the literature review are presented in Section 3, which shows the thematic synthesis analysis. In Section 4, we have the discussions and finally the conclusions and suggestions are presented in the last section.

\section{Background}

Since the 50's, Lean principles of the Toyota production system have evolved, and have been implemented successfully by the Toyota Motor Company (Aziz \& Hafez, 2013). They were formed by two main conceptions: Just-in-Time flow (producing according to the demand) and Jidoka automation (man-machine separation, in which a single operator manages several machines).

Lean Thinking offers a unique methodology, which is to do more with less - less human effort, less equipment, less staff and less space - in order to achieve the real needs of its clients. It results in the elimination of waste through more efficient processes, and that generates the essential capabilities a customer values (Comm \& Mathaisel, 2005).

In the last decade, Levitt's (1972) original model was revised and there was a re-industrialization of service with the adoption of the so-called lean service principles in many organizations (Abdi, Shavarini, \& Hoseini, 2006). Service companies that deploy the Lean approach quickly gain control of the key processes that deliver customer service, the practice of Lean behaviors helps to reduce ambiguity and re-work in interpersonal relationships and the Lean tools, such as value stream mapping and pull techniques, make people see the whole instead of only their part and thus, they come to understand better the paradox related to flexibility versus efficiency (Abdi et al., 2006).

Besides that, compared with the manufacturing processes, the service processes have more noise or uncontrollable factors, are subject to greater influence of human behavior characteristics and should devote more attention in timeliness and service non-conformity characteristics, which emphasizes the use of methodology Six Sigma, focused on improving service effectiveness and efficiency and reducing non-value added activities (Antony, 2004).

Six Sigma was created in the 1980's by Bill Smith at the Motorola Corporation, and seeks to reduce errors and defects by applying the DMAIC (Define, Measure, Analyze, Improve, and Control) methodology. Six Sigma is a highly disciplined process that helps organizations focus on delivering lower-cost products with improved quality and reduced cycle time, where Sigma represents a statistical term that measures the extent to which a given process deviates from perfection (Popa et al., 2005). 
Moreover, Six Sigma can help in developing skills, improving knowledge and skills, improving employee morale and the ability to use a wide range of tools, techniques and has the following advantages over total quality management: Establishing zero defaults targets, creating the DMAIC process improvement cycle, and intensive use of statistics and data to make managerial decisions and reduce process variation (Franchetti, 2015). However, it is crucial to have the Six Sigma connection with the strategy for successful deployment in service organizations (Antony, Kumar, \& Cho, 2007).

On the other hand, by focusing on process improvement and variability reduction, Six Sigma programs do not guarantee a sustainable competitive advantage, and mechanisms need to be developed that address innovation and product differentiation, the pattern of change in the customer base, and uncertainty environmental, while improving organizational processes, considering radical changes and the formation of new markets and / or customers (Parast, 2011).

As Ferguson (2007), Six Sigma is about exclusion (trains only a team for specific area or project), it encourages maintaining the status quo (tests hypotheses and uses control charts to avoid that processes are out-of-control), is aimed at realizing a level of improvement using DMAIC, and is considered a change management (focus on cost, quality, and schedule), while Lean is an inclusive philosophy that is all about continuous improvement (a neverending process) aimed at a transformational change, which involves the business strategy, organizational structure, culture, and processes of the entire value stream.

In addition, while the Lean philosophy can not statistically control a process, Six Sigma alone can not dramatically improve process speed or reduce invested capital (George, 2003). Because of that, it is essential to merge the two methodologies to reduce cost and complexity (George, 2002). These methodologies are complementary in terms of one making up for the limitations of the other (Goffnett, Lepisto, \& Hayes, 2016).

Both methodologies have become two of the most important initiatives for continuous improvement in organizations, improving processes through Six Sigma and productivity through Lean philosophy (Wang \& Chen, 2012; Gutierrez-Gutierrez, de Leeuw, \& Dubbers, 2016). Some of the advantages of the joint use of Lean and Six Sigma methodologies in services are the identification of the real causes for customer's dissatisfaction and defection (Lubowe \& Blitz, 2008), the improvement of responsiveness and efficiency in delivering customer demands (Antony, Escamilla, \& Caine, 2003; Psychogios \& Tsironis, 2012).

Lean Six Sigma (LSS) is a methodology of process improvement used in organizations of international standard in order to eliminate waste in the processes and deliver products and services with extreme quality to its clients (Popa et al., 2005). Furthermore, LSS can be considered a broad well-structured, systematic, strategic, integrated and long-term decision-making approach to improve quality, cost, speed, delivery and customer satisfaction performance that focuses on reducing variation in critical processes to achieve bottom-line benefits through merger of tools and principles of Lean and Six Sigma and enables organizations to meet and exceed customer expectations in a competitive global environment (Ray \& John, 2011; Laureani \& Antony, 2012; Nicoletti, 2013; Andersson, Hilletofth, Manfredsson, \& Hilmola, 2014; Gutierrez-Gutierrez et al., 2016).

The literature suggests that Lean and LSS approaches make a positive contribution to the sustainable performance of organisations and offer a better culture to deploy sustainability 
philosophies, tools and methods (Powell, Lundeby, Chabada, \& Dreyer, 2017; Cherrafi et al., 2017). Lean practices has some synergies with sustainability as waste reduction, reduction of environmental impacts as well as efficiency of water and conservation of energy, creation of greener supply chains, lead time reduction and techniques to manage people (Chiarini, 2014; Garza-Reyes, 2015a; Chugani et al., 2017), and this actions could be enhanced when Lean and Six Sigma are used together (Verrier, Rose, Caillaud, \& Remita, 2014).

As Gupta, Sharma, and Sunder (2016), the Lean approach is applicable in the context of the service, which is a knowledge intensive industry, and can be a valuable complement to the improvement of services that leads to customer satisfaction. Some of the important improvement tools used in services are value stream mapping, waste elimination, standardization, visual management / visual control, 5S, Human Resources (HR) management and Kaizen.

Besides that, some of the critical factors for the success of the LSS methodology in services are customer satisfaction (Kondić \& Maglić, 2008), the enthusiasm, support and commitment of top management, LSS's connection to business strategy, its connection to training, and education (Manville et al., 2012) and the personal experience of senior management team members with LSS projects, the development of leadership skills (Timans et al., 2012). Hilton and Sohal (2012) also argue that the success of LSS deployment depends on the level of influence as well as the levels of technical and interpersonal competence of the facilitators who manage and lead the projects. On the other hand, factors such as internal resistance, lack of resources, changing business objectives and lack of leadership impede success (Tsironis \& Psychogios, 2016).

Therefore, in light of the increasing importance of the service sector, the key message is that the integration of Lean and Six Sigma aims to incorporate the problem-solving and analysis tools to meet quality management standards, save costs and also meet sustainable services. It is necessary to view services as a system, considering Lean Service as a strategic approach that places the customers at the centre and invests in mechanisms of engagement of the employees at the team and individual levels. In addition, Six Sigma could be used in order to achieve stable and predictable process results and it encourages creating a process thinking mind-set in the organization. Hence, LSS uses tools from both toolboxes, in order to get the synergetic-best of the two methodologies, being essential to enhance customer satisfaction and triple bottom line results as well as to improve KPIs and to foster sustainable development.

\section{Methodology}

In this paper was conducted a systematic literature review in order to locate relevant existing studies based on prior formulated research questions, to evaluate and synthesize their respective contributions. In this review, just as Caiado et al. (2017) and Saieg, Dominguez, Nascimento, and Caiado (2018) many articles were read, focusing on the scope of the research and limiting the sample to selecting, evaluating, and interpreting only relevant and adherent works for the particular subject. This SLR consists of five consecutive phases: (a) formulation of the question, (b) location of studies, (c) evaluation and selection of studies, (d) analysis and synthesis, and (e) reporting and use of the results (Garza-Reyes, 2015b). 
Identifying the keywords is extremely critical to a comprehensive and unbiased review. The search is limited to a set of search terms ('Lean', 'Six Sigma,' 'Lean Sigma', 'Lean Six Sigma', 'LSS, 'Environment', 'Sustainable, 'Sustainability', 'Green', 'Green Lean Six sigma', 'Green LSS', 'Sustainable Lean Six Sigma' and 'Service'). We searched these keywords in the following databases: Scopus, ISI Web of Science, PubMed, Emerald, Taylor and Francis, IEEE Xplore and Wiley Publication. The conducted research had combined the search terms into title, abstract or keywords, limited to papers published in peer-reviewed journals up to March 2017, when they were available. Additional papers were identified by reading the papers included in the review. 272 records were identified through databases searching. Then, they were refined by titles/abstracts screening analysis and 207 records were excluded. Following that, 65 articles were analized in depth in an interative process. Based on the full text analysis, a total of 43 articles complied with the selection criteria. Hence these were all the articles that, to a certain extent, referred to Lean, Six Sigma or Lean Six Sigma related to sustainable development in services.

In the next stage, researchers discussed and created a database using Microsoft Excel. There was a synthesis analysis, in which individual articles were categorized and organized by concepts.

\section{Results}

Table 1 indicates some of the main compatibilities and divergences between green and Lean / Lean Six Sigma approaches in the service industry, including general points for all sectors.

As Azevedo et al. (2012), the Green paradigm aims to minimize environmental impact, while the Lean paradigm seeks to minimize waste, but there is a set of green practices, as "using green purchasing guidelines and sourcing from environmentally responsible sources", and Lean practices, as "just-in-sequence" and "deliveries directly to the point of use", that could positively influence economic, social and environmental measures. From this, it is also vital to investigate approaches for delivering products and services without endangering the environment, society and the return on investment, concept called triple bottom line (TBL) sustainable performance (Garza-Reyes, 2015b).

Lean, environmental, and social management systems should be combined to assess sustainability in a broader sense, focusing on environmental issues or issues related to corporate social responsibility. This will contribute to overall performance, brings financial gains, regulatory compliance and penalty prevention, talent and greater employee retention and better market position and greater reputation (Haddach, Ammari, \& Laglaoui, 2016).

According to Dües et al. (2013), the synergy between the Lean and Green paradigms could be described by the equation $1+1=3$, since one practice improves the other, generating a result greater than the sum of the separated performances. Moreover, if the strategy and goal of a basic organizational business model is to reduce waste and maximize profit, integrated Lean and Green principles will be more effective than other methods to deliver a specific result (Wiese et al., 2015).

Besides that, Table 2 shows some challenges and enablers of the alignment between Green and Lean/LSS operational programs. 
Table 1. Compatibilities and divergences between Green and Lean / LSS

\begin{tabular}{|c|c|c|}
\hline Compatibilities & Source(s) & Themes \\
\hline $\begin{array}{l}\text { Green practices as "using green purchasing guidelines and sourcing } \\
\text { from environmentally responsible sources" contributes to the } \\
\text { improvement of businesses' social performance. Lean practices } \\
\text { as "deliveries directly to the point of use" and "geographical } \\
\text { concentration" could influence positively the local community, } \\
\text { through job creation, infrastructure development, and collaboration } \\
\text { with universities and knowledge centers. Synergies can be used to } \\
\text { facilitate supplier monitoring by providing an early warning system } \\
\text { and timely recognition and prevention of environmental and social } \\
\text { irregularities in the upstream supply chain }\end{array}$ & \begin{tabular}{|l|} 
Azevedo, \\
Carvalho, \\
Duarte, and \\
Cruz-Machado \\
$(2012)$
\end{tabular} & $\begin{array}{l}\text { Lean and } \\
\text { green }\end{array}$ \\
\hline $\begin{array}{l}\text { Lean serves as a catalyst for the implementation of Green, which in } \\
\text { turn generates benefits for existing business practices, and both have } \\
\text { waste reduction techniques, while green waste can be incorporated } \\
\text { into Lean wastes and simultaneously reduced, they seek to reduce } \\
\text { cycle time, relate to the supply chain, have key performance } \\
\text { indicators as the service level, and share tools and practices }\end{array}$ & $\begin{array}{l}\text { Dües, Tan, and } \\
\operatorname{Lim}(2013)\end{array}$ & $\begin{array}{l}\text { Lean and } \\
\text { Green }\end{array}$ \\
\hline $\begin{array}{l}\text { Lean and Green can be also integrated into other models like } \\
\text { ISO } 9001 \text { and } 14001\end{array}$ & $\begin{array}{l}\text { Kurdve, } \\
\text { Zackrisson, } \\
\text { Wiktorsson, } \\
\text { and Harlin } \\
(2014)\end{array}$ & $\begin{array}{l}\text { Lean and } \\
\text { green }\end{array}$ \\
\hline $\begin{array}{l}\text { Lean tools and practices may facilitate the focus on sustainability at } \\
\text { the operational level }\end{array}$ & $\begin{array}{l}\text { Verrier et al. } \\
(2014)\end{array}$ & $\begin{array}{l}\text { Lean and } \\
\text { green }\end{array}$ \\
\hline $\begin{array}{l}\text { Lean facilitates sustainability, and people integration is the key to } \\
\text { Lean success, which drives the organization towards sustainable } \\
\text { operations management. Sustainable processes reduce ecological } \\
\text { impacts and may eliminate wasteful depletion of scarce resources. } \\
\text { The synergies from the horizontal and vertical directions of human } \\
\text { integration can lead to value creation in the organization }\end{array}$ & $\begin{array}{l}\text { W. P. Wong } \\
\text { and K. Y. } \\
\text { Wong (2014) }\end{array}$ & $\begin{array}{l}\text { Lean and } \\
\text { green }\end{array}$ \\
\hline $\begin{array}{l}\text { Lean and Green maintain synergies related to waste reduction, lead } \\
\text { time reduction, product design and the use of various approaches } \\
\text { and techniques to manage people, organisations and the supply } \\
\text { chain }\end{array}$ & $\begin{array}{l}\text { Garza-Reyes } \\
(2015 a)\end{array}$ & $\begin{array}{l}\text { Lean and } \\
\text { green }\end{array}$ \\
\hline $\begin{array}{l}\text { Lean and Green thinking focuses on improving business results } \\
\text { in terms of cost, market position, product reputation and design, } \\
\text { and improving customer value by collaborating with suppliers } \\
\text { and customers, analyzing existing operations, and identifying } \\
\text { opportunities to reduce the waste operating more efficiently }\end{array}$ & $\begin{array}{l}\text { Wiese, Luke, } \\
\text { Heyns, and } \\
\text { Pisa (2015) }\end{array}$ & $\begin{array}{l}\text { Lean and } \\
\text { green }\end{array}$ \\
\hline $\begin{array}{l}\text { The use of the DMAIC (define-measure-analyse-improve-control) } \\
\text { model can provide Green Lean with a more specific and holistic } \\
\text { project-based orientation to the implementation of Green Lean } \\
\text { initiatives. }\end{array}$ & $\begin{array}{l}\text { Cherrafi et al. } \\
(2016)\end{array}$ & $\begin{array}{l}\text { LSS and } \\
\text { green }\end{array}$ \\
\hline $\begin{array}{l}\text { The combination of the seven deadly wastes of Lean Management } \\
\text { and the } 3 \mathrm{R} \text { (Reduction / Reuse / Recovery) hierarchy in a Lean / } \\
\text { Green matrix improves the performance of a manufacturing } \\
\text { minimization program }\end{array}$ & $\begin{array}{l}\text { Fercoq, } \\
\text { Lamouri, } \\
\text { and Carbone } \\
(2016)\end{array}$ & $\begin{array}{l}\text { Lean and } \\
\text { green }\end{array}$ \\
\hline
\end{tabular}


End of Table 1

\begin{tabular}{|c|c|c|}
\hline Compatibilities & Source(s) & Themes \\
\hline $\begin{array}{l}\text { Many Lean practices increase the level of "transparency" of the } \\
\text { workplace, such as clear visibility of hazards and a cleaner working } \\
\text { environment so that workers have the opportunity to identify, } \\
\text { evaluate and suggest controls (such as visual and other signs } \\
\text { visualization artifacts) that make human / technological interaction } \\
\text { more effective and help reduce health and safety hazards in the } \\
\text { workplace, helping to address the human side of organizational } \\
\text { sustainability. }\end{array}$ & \begin{tabular}{|l|} 
Camuffo, De \\
Stefano, and \\
Paolino (2017)
\end{tabular} & $\begin{array}{l}\text { Lean and } \\
\text { green }\end{array}$ \\
\hline $\begin{array}{l}\text { Just like Lean, Green advocates the elimination of seven wastes: } \\
\text { unnecessary usage of water, unnecessary power usage, exploitation } \\
\text { of resources, pollution, litter, greenhouse effects and eutrophication }\end{array}$ & $\begin{array}{l}\text { Chugani et al. } \\
\text { (2017) }\end{array}$ & $\begin{array}{l}\text { Lean and } \\
\text { green }\end{array}$ \\
\hline Divergences & Source(s) & Themes \\
\hline $\begin{array}{l}\text { These paradigms diverge as to focus, what is considered as waste, } \\
\text { customer, product design and manufacturing strategy, end of life } \\
\text { product management, KPIs, the dominant cost, the main tool used } \\
\text { and certain points As the frequency of replacement. It is hoped that } \\
\text { trade-offs will be made between multiple objectives. While Lean } \\
\text { practices focus on maximizing performance and reducing costs, } \\
\text { green practices apply life cycle assessment (LCA) to design products } \\
\text { for environmental optimization at each stage of the lifecycle }\end{array}$ & $\begin{array}{l}\text { Dües et al. } \\
(2013)\end{array}$ & $\begin{array}{l}\text { Lean and } \\
\text { green }\end{array}$ \\
\hline $\begin{array}{l}\text { Green is focused on environmental performance, Lean is focused on } \\
\text { waste and its elimination and Six Sigma focuses on the continuous } \\
\text { improvement of quality of products and services in an organisation } \\
\text { by minimising the defects }\end{array}$ & \begin{tabular}{|l|} 
S. Kumar, \\
Luthra, \\
Govindan, N. \\
Kumar, and \\
Haleem (2016)
\end{tabular} & $\begin{array}{l}\text { LSS and } \\
\text { green }\end{array}$ \\
\hline $\begin{array}{l}\text { Sustainability is concerned with the capability of meeting those } \\
\text { needs in the present and future (efficacy, effectiveness and ethics), } \\
\text { whereas Lean is more oriented to delivering products or services } \\
\text { with the minimum use of resources (efficiency and effectiveness) }\end{array}$ & \begin{tabular}{|l|} 
Martínez \\
León and \\
Calvo-Amodio \\
$(2017)$
\end{tabular} & $\begin{array}{l}\text { Lean and } \\
\text { green }\end{array}$ \\
\hline $\begin{array}{l}\text { While Lean is more concerned with respecting people, including } \\
\text { customers and employees, sustainability appears to expand the } \\
\text { concern by seeking the well-being of all stakeholders in the long } \\
\text { term }\end{array}$ & \begin{tabular}{l|} 
Martínez \\
León and \\
Calvo-Amodio \\
$(2017)$
\end{tabular} & $\begin{array}{l}\text { Lean and } \\
\text { green }\end{array}$ \\
\hline
\end{tabular}

Therefore, Lean is an integrated socio-technical system (Tortorella, Vergara, \& Ferreira, 2017) and must be complemented by green practices in order to achieve sustainable development. For this, as seen in Table 2, from the internal point of view it is essential that there be strategic orientation to the Green-Lean practices, with support and leadership of the top management, linking this to strategic planning. In addition, it is important to have a culture engaged with empowered and committed people and the management of knowledge generated from experiences. From the external point of view, it is necessary to have regulations and standards for the sector, supply chain integration with the correct and ethical use of appropriate tools and practices, strengthening alliances with partners and involving all internal and external stakeholders. 
Table 2. Challenges and enablers to Green-Lean or Green LSS in organizations

\begin{tabular}{|c|c|c|}
\hline Challenges & Enablers & Source(s) \\
\hline $\begin{array}{l}\text { To know how to deploy Lean and Green } \\
\text { as a systematic way, implementing the } \\
\text { Green-Lean culture through all areas } \\
\text { of an organization and its supply chain, } \\
\text { considering the minimization of trade- } \\
\text { offs between the two approaches and } \\
\text { recognizing the "ideal formula" for each } \\
\text { business }\end{array}$ & $\begin{array}{l}\text { To create an appropriate culture, have } \\
\text { a leadership commitment, have a } \\
\text { Lean and Green adequate structure, } \\
\text { engage all employees, set the right } \\
\text { strategy for transformation, and make } \\
\text { a long-term alliance with partners }\end{array}$ & $\begin{array}{l}\text { Duarte } \\
\text { and Cruz- } \\
\text { Machado } \\
(2009)\end{array}$ \\
\hline $\begin{array}{l}\text { To improve social and environmental } \\
\text { aspects but also to achieve operational } \\
\text { improvements in logistics processes }\end{array}$ & $\begin{array}{l}\text { Some internal adaptations and } \\
\text { changes must be made previously, } \\
\text { requiring strategic orientation, } \\
\text { organizational structure and the } \\
\text { ability to explore market information } \\
\text { and innovate; have stronger links } \\
\text { with key suppliers and train a team } \\
\text { through classrooms and Lean events }\end{array}$ & $\begin{array}{l}\text { Azevedo } \\
\text { et al. (2012) }\end{array}$ \\
\hline $\begin{array}{l}\text { Make managers and executives rethink the } \\
\text { organizations approach to environmental } \\
\text { practices and clarify the confusion about } \\
\text { what is really green, given that there are few } \\
\text { models, regulations, and best practices to } \\
\text { support their implementation }\end{array}$ & $\begin{array}{l}\text { It is necessary to establish regulations } \\
\text { and standards to translate green } \\
\text { costs into financial terms in order to } \\
\text { compare Green and Lean measures } \\
\text { across the supply chain of different } \\
\text { industries, such as services. }\end{array}$ & $\begin{array}{l}\text { Dües et al. } \\
(2013)\end{array}$ \\
\hline $\begin{array}{l}\text { Simultaneously develop Lean and Green } \\
\text { methodologies, seeking environmental } \\
\text { benefits and productivity together and in an } \\
\text { active rather than "incidental" manner and } \\
\text { incorporate economic considerations into } \\
\text { green tools }\end{array}$ & $\begin{array}{l}\text { Existence of a sustainability } \\
\text { champion who understands all triple } \\
\text { bottom line dimensions and objectives } \\
\text { of sustainability with integrated use of } \\
\text { Lean tools and green methodologies } \\
\text { and communicates environmental and } \\
\text { business issues to all stakeholders, } \\
\text { expanding improvements along the } \\
\text { supply chain }\end{array}$ & $\begin{array}{l}\text { Dhingra, } \\
\text { Kress, and } \\
\text { Upreti (2014) }\end{array}$ \\
\hline $\begin{array}{l}\text { Change management that includes } \\
\text { employees, suppliers, customers and human } \\
\text { virtues (attitude and behavior), such as } \\
\text { leadership, teamwork, cooperation, habits, } \\
\text { etc. }\end{array}$ & $\begin{array}{l}\text { Focus on knowledge management, } \\
\text { seeking to extract, compile, preserve } \\
\text { and share the knowledge gained } \\
\text { through experience }\end{array}$ & $\begin{array}{l}\text { Jadhav } \\
\text { Mantha, and } \\
\text { Rane (2014) }\end{array}$ \\
\hline $\begin{array}{l}\text { Implement Lean and Green business } \\
\text { strategies to recognize savings and develop } \\
\text { best practice solutions that enhance and } \\
\text { sustain business competitiveness within an } \\
\text { industry }\end{array}$ & $\begin{array}{l}\text { Commitment to Lean and Green } \\
\text { business principles and determination } \\
\text { of a clear link between the company's } \\
\text { environmental approach, the basic } \\
\text { principles and established culture of } \\
\text { best practice }\end{array}$ & $\begin{array}{l}\text { Wiese et al. } \\
(2015)\end{array}$ \\
\hline $\begin{array}{l}\text { Ensure involvement of managers and } \\
\text { leaders, select the right people based on } \\
\text { leadership skills and psychological factors, } \\
\text { identify the concerns and sustainability } \\
\text { priorities of stakeholders, select the right } \\
\text { and appropriate tools }\end{array}$ & $\begin{array}{l}\text { The effective implementation of } \\
\text { Green LSS (GLSS) depends on greater } \\
\text { attention in key points: (i) leadership } \\
\text { and people, (ii) Green and Lean } \\
\text { Six Sigma tools, (iii) continuous } \\
\text { process improvement, (iv) strategic } \\
\text { planning, Vi) results and knowledge } \\
\text { management. }\end{array}$ & $\begin{array}{l}\text { Cherrafi et al. } \\
(2016)\end{array}$ \\
\hline
\end{tabular}


End of Table 2

\begin{tabular}{|l|l|l|}
\hline \multicolumn{1}{|c|}{ Challenges } & \multicolumn{1}{|c|}{ Enablers } & \multicolumn{1}{c|}{ Source(s) } \\
\hline $\begin{array}{l}\text { Developing people, pushing them to work } \\
\text { better in a constructive way, developing } \\
\text { their problem-solving and project } \\
\text { management skill sets and empowering } \\
\text { them to become better and more efficient } \\
\text { problem solvers, to consider the ethical } \\
\text { issue by uniting efforts Green Lean and } \\
\text { concern about responsible selection of } \\
\text { resources (focus on renewables) and not } \\
\text { only on their efficient use. }\end{array}$ & $\begin{array}{l}\text { An appropriate mix of Lean-for- } \\
\text { sustainability practices should be } \\
\text { focused at the design stage where } \\
\text { structural changes can be applied. } \\
\text { A systemic approach is needed to } \\
\text { promote the appropriate degree of } \\
\text { flexibility, human asset should be the } \\
\text { focal point of improvement changes }\end{array}$ & $\begin{array}{l}\text { León and } \\
\text { Calvo- } \\
\text { Amodio } \\
(2017)\end{array}$ \\
\hline $\begin{array}{l}\text { Relationship with external stakeholders, } \\
\text { improving the communication channel to } \\
\text { understand their needs }\end{array}$ & $\begin{array}{l}\text { To take a holistic and systemic } \\
\text { approach to corporate sustainability } \\
\text { and make it part of companies' } \\
\text { cultures and activities. }\end{array}$ & $\begin{array}{l}\text { Lozano, } \\
\text { Suzuki, } \\
\text { Carpenter, } \\
\text { and Tyunina } \\
\text { (2017) }\end{array}$ \\
\hline
\end{tabular}

\section{Discussion}

Table 3 portrays some implications about how different services could achieve green through Lean and Lean Six Sigma.

As stated by Suárez-Barraza, Smith, and Dahlgaard-Park (2012) more than reach cost reduction and failures correction, we expect that Green LSS service focus on a cultural change, bringing a new sense of discovery, experience or re-discovery internally and externally, maximising a collaborative value creation, developing new behaviours and skills for employees and delivering environmental-friendly services to the clients.

As seen in education services, there must be advanced planning and management commitment with cultural change in college or university to show the benefits that re-allocation and restructuring can generate. In addition, we must seek the understanding and integration between the administrative and academic side to implement a sustainable lean structure, because in the future this issue will be even more important for higher education (Comm and Mathaisel, 2003).

However, for Lean sustainability to succeed in higher education, there must be a topdown approach, starting from the top and then spreading to the rest of the school. These practices are a good fit for higher education as they help universities identify which areas help education thrive and survive, and whether or not to invest in those areas, thereby improving services at a reduced cost (Comm \& Mathaisel, 2005).

The Lean and Green transformation is a long-term journey, a new form of strategy and a new form of management that must be built around values of sustainability and excellence in order to model a Green-Lean business culture with specific tools and principles, according to the business models (Duarte \& Cruz-Machado, 2009). It is also necessary for managers to have a complete and strategic perspective of the organization to customize the LSS implementation and to extrapolate solutions and positive experiences to their processes, considering the particularities of their organizational context (Gutierrez-Gutierrez et al., 2016). 
Table 3. Implications of Lean and LSS for achieving sustainability

\begin{tabular}{|c|c|c|}
\hline Sectors & Implication & Source(s) \\
\hline \multirow{5}{*}{ Education } & $\begin{array}{l}\text { The university can become Lean using the "value stream } \\
\text { mapping" (VSM) technique and using benchmarking to } \\
\text { encourage improvement in product volume and quality, reducing } \\
\text { a university's operating costs and increasing profits to maintain } \\
\text { and / or strengthen their position in an increasingly competitive } \\
\text { environment. The use of benchmarking can provide a university } \\
\text { with a better understanding of the needs of its clients (students). } \\
\text { Thus Lean sustainable initiatives in terms of reallocation and / or } \\
\text { restructuring can benefit a university by generating more future } \\
\text { value. }\end{array}$ & $\begin{array}{l}\text { Comm and } \\
\text { Mathaisel } \\
(2003)\end{array}$ \\
\hline & $\begin{array}{l}\text { The focus on higher education lies in the implementation of } \\
\text { cost reduction or budget containment initiatives, Lean practices } \\
\text { that generally reduce waste, improve operational efficiency and } \\
\text { contribute to sustainability. Due to government constraints, } \\
\text { public schools are driven to the operational dynamics of Lean } \\
\text { initiatives more quickly while private schools resist Lean for } \\
\text { fear of being seen with lesser quality. The most popular Lean } \\
\text { practices are outsourcing non-core services, collaboration with } \\
\text { other schools or organizations, and leveraging technology. }\end{array}$ & $\begin{array}{l}\text { Comm and } \\
\text { Mathaisel } \\
(2005)\end{array}$ \\
\hline & $\begin{array}{l}\text { The education system must adjust to meet customer expectations } \\
\text { at a high-quality, just-in-time level, as well as the modern } \\
\text { green Product Lifecycle Management, and the manufacturing / } \\
\text { automation industry does. Quality educational methods that } \\
\text { stimulate students, case-based learning objects (using interactive } \\
\text { 3D eBooks, supported by DVD and HD videos) to encourage } \\
\text { team-oriented analysis and teaching-learning and problem } \\
\text { solving with real-world challenges. }\end{array}$ & $\begin{array}{l}\text { Ranky and } \\
\text { Kalaba (2012) }\end{array}$ \\
\hline & $\begin{array}{l}\text { Courses should combine Lean and Green thinking to teach } \\
\text { these concepts and approaches, and also integrate studies } \\
\text { such as green productivity, eco-efficiency, eco-effectivity, and } \\
\text { sustainable business practices. University schools of business and } \\
\text { engineering could be ideal candidates for incorporating these } \\
\text { curricular changes. }\end{array}$ & $\begin{array}{l}\text { Dhingra et al. } \\
(2014)\end{array}$ \\
\hline & $\begin{array}{l}\text { Creating an environmentally sustainable building - applying } \\
\text { Lean basics principles for delivering sustainable services, support } \\
\text { processes and workflows - which will be a hub for collections } \\
\text { that move between campus libraries and across libraries across } \\
\text { the country province with which the university has fundamental } \\
\text { partnerships. The efficiency of the library is sought by efficiently } \\
\text { delivering a relatively small number of highly specific and } \\
\text { individualized services to a large, diverse and widely distributed } \\
\text { customer base. } \\
\text { According to the Lean principle of pulling from the customer, } \\
\text { providing specialized services for a fee ensures that the } \\
\text { university library is only delivering what users are willing to } \\
\text { pay. While many of the leading library services respond to the } \\
\text { historical expectations of the service and the expressed needs } \\
\text { of users, others are designed to anticipate needs and grow over } \\
\text { time, such as search metrics. }\end{array}$ & $\begin{array}{l}\text { Beasley and } \\
\text { Rosseel (2016) }\end{array}$ \\
\hline
\end{tabular}


Continue of Table 3

\begin{tabular}{|c|c|c|}
\hline Sectors & Implication & Source(s) \\
\hline General & $\begin{array}{l}\text { It is important that employees have a deep understanding of } \\
\text { the concepts underpinning green and Lean practice and the } \\
\text { employee development processes must be linked to the overall } \\
\text { green and Lean transformation process, because human capital is } \\
\text { at the very core of green and Lean practice. }\end{array}$ & $\begin{array}{l}\text { Zhan, Tan, Ji, } \\
\text { Chung, and } \\
\text { Chiu (2015) }\end{array}$ \\
\hline Air & $\begin{array}{l}\text { It is important to reduce fuel consumption by eliminating } \\
\text { network redundancy and by reorganizing hub networks, and } \\
\text { balancing this against possible service level degradation. }\end{array}$ & $\begin{array}{l}\text { Ryerson and } \\
\text { Kim (2014) }\end{array}$ \\
\hline Offices & $\begin{array}{l}\text { The research highlights the relevance of Lean, particularly the } \\
\text { application of muda - waste in Japanese - (such as on perceived } \\
\text { job productivity) as enhancement of users' requirement } \\
\text { assessment for the sustainable improvement diagnosis technique } \\
\text { of existing office buildings in Nigeria. Besides tangible waste } \\
\text { as garbage, refuse, scraps, this study also shows that intangible } \\
\text { waste has also been identified, promoted by models such as Lean } \\
\text { Thinking and Zero Emissions and considers waste in a different } \\
\text { perspective in environmental management. }\end{array}$ & $\begin{array}{l}\text { Adeyemi, } \\
\text { Martin, and } \\
\text { Kasim (2017) }\end{array}$ \\
\hline Sales & $\begin{array}{l}\text { Green may be a useful support to Six Sigma as a programme that } \\
\text { helps to save resources. }\end{array}$ & $\begin{array}{l}\text { Wei, Sheen, } \\
\text { Tai, and Lee } \\
\text { (2010) }\end{array}$ \\
\hline \multirow{4}{*}{$\begin{array}{l}\text { Food } \\
\text { processing }\end{array}$} & $\begin{array}{l}\text { It is perceived that the Value Stream Mapping analysis, a basic } \\
\text { Lean Thinking tool, can be used effectively and efficiently } \\
\text { for a series of improvements not only to identify wastes, but } \\
\text { synergistically with green initiatives for the determination of } \\
\text { Greening the supply chain of agrifood products, a large and } \\
\text { complex chain. It is necessary to balance points of conflict and } \\
\text { understand the various trade-offs between Lean and Green to } \\
\text { deal with the complex network of entities and interactions of the } \\
\text { agrifood chain. }\end{array}$ & $\begin{array}{l}\text { Folinas, } \\
\text { Aidonis, } \\
\text { Triantafillou, } \\
\text { and } \\
\text { Malindretos } \\
(2013)\end{array}$ \\
\hline & $\begin{array}{l}\text { This work explores the application of the VSM tool, considered } \\
\text { viable to determine the waste in a specific agrifood supply chain } \\
\text { of the maize product for animal feed. VSM has been suggested } \\
\text { to determine waste in terms of water, energy and delivery time } \\
\text { of the production process. The introduction of global supply } \\
\text { chain management in the Green and Lean equation increases } \\
\text { the potential conflict between these initiatives, so it is necessary } \\
\text { to balance possible points of conflict, especially when there is a } \\
\text { decline in the agrifood sector. }\end{array}$ & $\begin{array}{l}\text { Folinas, } \\
\text { Aidonis, } \\
\text { Malindretos, } \\
\text { Voulgarakis, } \\
\text { and } \\
\text { Triantafillou } \\
(2014)\end{array}$ \\
\hline & $\begin{array}{l}\text { The important tools of implementing Lean supply chain include } \\
\text { the collaboration of the demand, continuous improvement, } \\
\text { inventory management practices, value-added activities, reducing } \\
\text { waste, company and industry standard, human resources, data } \\
\text { pattern, planning and Standardization of the production process, } \\
\text { sales and operations planning and demand signal. }\end{array}$ & $\begin{array}{l}\text { Manzouri, Ab- } \\
\text { Rahman, Zain, } \\
\text { and Jamsari } \\
(2014)\end{array}$ \\
\hline & $\begin{array}{l}\text { Lean Six Sigma might be successfully applied in the food } \\
\text { processing industry through VSM-DMAIC, in which the value } \\
\text { stream mapping - is used to identify the type of waste and the } \\
\text { DMAIC improvement cycle was applied in order to understand } \\
\text { and address the wastes by applying relevant Lean and Six Sigma } \\
\text { tools. Also, LSS can be effectively applied in the food processing } \\
\text { industry as a contributor toward the environmentally sustainable } \\
\text { fresh food supply chain. }\end{array}$ & $\begin{array}{l}\text { Powell et al. } \\
(2017)\end{array}$ \\
\hline
\end{tabular}


End of Table 3

\begin{tabular}{|c|c|c|}
\hline Sectors & Implication & Source(s) \\
\hline $\begin{array}{l}\text { Information } \\
\text { and } \\
\text { Communication } \\
\text { Technologies } \\
\text { (ICTs) }\end{array}$ & $\begin{array}{l}\text { In this age of science and information, it is important to build } \\
\text { bridges between disciplines, between academics and industry. } \\
\text { More specifically, the field of Life Cycle Assessment (LCA) } \\
\text { can adopt and apply a substantial amount of tools and lines of } \\
\text { thought from operational management such as the Lean heritage } \\
\text { and six sigma and vice versa. }\end{array}$ & $\begin{array}{l}\text { De Soete } \\
(2016)\end{array}$ \\
\hline Banking & $\begin{array}{l}\text { The LSS project management approach was adopted in banking } \\
\text { and financial services, organizations that are at high risk at } \\
\text { all levels of decisions taken to implement change. Stakeholder } \\
\text { management becomes the key element, employee collaboration } \\
\text { and engagement being an important feature for the success of } \\
\text { the LSS in a bank or financial institution. }\end{array}$ & $\begin{array}{l}\text { Vijaya Sunder } \\
(2016)\end{array}$ \\
\hline Petroleum & $\begin{array}{l}\text { LSS concepts, specifically Value Stream Mapping (VSM) and } \\
\text { Value Stream Analysis (VSA) were performed to investigate } \\
\text { underperforming activities in the support service for the } \\
\text { maintenance of sustainable petroleum operations, allowing } \\
\text { to reduce the barriers to maintaining sustainable petroleum } \\
\text { operations, minimizing waste in the engineering contractors } \\
\text { and asset owners' organizations and indicating possible } \\
\text { improvements in overall TBL sustainable performance. }\end{array}$ & $\begin{array}{l}\text { Ratnayake } \\
\text { and Chaudry } \\
(2017)\end{array}$ \\
\hline Logistics & $\begin{array}{l}\text { Lean practices implemented to improve inventory management } \\
\text { at the retail level can contribute to a reduced amount of } \\
\text { greenhouse gas emissions. With this, capacity development } \\
\text { and supply chain flexibility can be achieved through strategic } \\
\text { investments at the retail level, such as the adoption of product } \\
\text { postponement practices and Vendor Managed Inventory. Thus, } \\
\text { under certain operating conditions, just-in-time systems can be } \\
\text { lean, reducing the overall carbon intensity of the supply chain. }\end{array}$ & $\begin{array}{l}\text { Ugarte, } \\
\text { Golden, and } \\
\text { Dooley (2016) }\end{array}$ \\
\hline Heathcare & $\begin{array}{l}\text { While lean approach is used to reduce the use of water, materials } \\
\text { and pharmaceuticals in medication processes, without, however, } \\
\text { undermining patient safety, Six Sigma approach is used to } \\
\text { monitor actions before and after interventions and improve } \\
\text { medication processes from the point of view of environmental } \\
\text { sustainability. Thus, they must complement each other and the } \\
\text { LSS is method by which hospitals can control costs, reduce } \\
\text { the likelihood of errors and improve patient safety and health } \\
\text { care quality, promoting sustainability practices yields not } \\
\text { only environmental benefits, but also economic ones for the } \\
\text { institution. }\end{array}$ & $\begin{array}{l}\text { Furukawa, } \\
\text { Cunha, and } \\
\text { Pedreira } \\
(2016)\end{array}$ \\
\hline
\end{tabular}

Based on the above implications, it was shown that there is a need for more holistic approaches aligning Lean, Six Sigma key concepts and tools with green practices. From the literature review, it was discovered that by integrating Green and Lean/LSS in service processes it will facilitate the organization in managing and assuring customer needs, dealing with qualities and strategies, and considering the welfare of all stakeholders, thus improving the TBL performance in an integrated way. In addition, based on the derived insights, a conceptual framework to implement Green Lean Six Sigma in services was proposed (Figure 1). Therefore, it attempts to help practitioners to identify opportunities in Lean and Six 
Sigma not only towards operational excellence but also to fulfil their responsibility towards the environment in a collective effort.

Based on the above discussion, the conceptual framework points out nine critical factors to implement GLSS in services: continuous customer satisfaction, long-term comunication with entire supply chain, ethic relations and regulatory compliance, team training and empowerment, leadership commitment, integrated TBL-KPIs, strategy and culture for tranformation, focus on knowledge management and human behavior, and effective Jidoka automation.

Moreover, the both cultural change and implementation of LSS tools and principles can ensure sustainability and critical aspects as respect for people and employee engagement depends on responsibility along with ownership, human-centric approach, deeper problemsolving capabilities and cross-functional relationship, which are fundamental for continuous improvement (Gupta et al., 2016). It is also observed that workers' empowerment and capability development are behaviors that positively impact workers' safety, which corroborate studies on what type of Lean leadership is needed to foster the human side of organizational sustainability and to support socially sustainable operations (Camuffo et al., 2017)

In addition, some key tools for improving services through the use of Green and Lean practices are: VSM, waste elimination, standardization, visual management / visual control,



Figure 1. Integrated framework to implement Green Lean Six Sigma in services 
Human Resources management and Kaizen. An essential requirement for using these tools is employee collaboration and engagement, as human capital is at the heart of Green-Lean integration. On the other hand, it is still necessary to understand the various trade-offs between Lean and Green.

Regarding the integration of Lean and Six Sigma into services, it is observed that while Lean adds value to services, eliminating redundancies and reorganizing networks in the case of information and communication technology services; Six Sigma is used to monitor actions before and after interventions and to improve processes from the point of view of environmental sustainability; and LSS helps control costs, reduce the likelihood of errors, and improve consumer safety in the health area. One of Lean Six Sigma's main tools is VSMDMAIC, in which value stream mapping is used to identify the type of waste and the DMAIC improvement cycle has been applied to understand and resolve waste.

\section{Conclusions}

Hence, this research aims to contribute to the scientific community on the theme studied, since it present a representative selection of international research in interdisciplinary area as it is a relevant issue in which there is a dialogue of sustainability science, business management and industrial engineering, enabling the researchers to contribute with relevant research. It is expected that the proposed framework benefit both researchers and industrialists in gaining valuable information on the influence of Lean and Six Sigma practices in increasing corporate TBL-sustainability, and thereby provide new paradigms and pathways to achieve a balance in technical, economic, social and environmental priorities in sustainable business practices.

The paper reviewed the evolution of published research on Lean Thinking and Lean Six Sigma focused on sustainability in Services, to comprehend what Lean/LSS is in sustainable services, to classify the studies and suggest points of attention for scholars and practitioners to carry out future research. The majority of the research on the application of Lean and Green practices has talked about them as a complementary and integrated approach. Studies of the application of a Green LSS methodology to a service enterprise are missing.

Finally, the study's limitations and suggestions for future studies are presented. Firstly, more in-depth research can be done in order to improve the findings as the proposal of an integrated Green Lean Six Sigma business model or a roadmap to implement green LSS in service industry. The continuity of the research on this theme can lead to new ways of better understanding the integration of Lean Six Sigma, sustainability and services.

As a sequence to this work, aside from the possibility of counting on descriptive analysis through bibliometric analysis, we suggest the application of a survey with different service organizations to perform statistical analyzes or an in-depth case study by interviewing professionals from a service company applying LSS tools and having environmental concerns. Also, it is recommended that future studies explore the application of the LSS and green best practices in other industries and comparative studies explore the application of it in different countries. 


\section{Acknowledgements}

The research is supported by the Brazilian Federal Agency for Support and Assessment of Post-graduate Education (CAPES).

\section{Disclosure statement}

This work does not have any competing financial, professional, or personal interests from other parties

\section{References}

Abdi, F., Shavarini, S. K., \& Hoseini. S. M. S. (2006). Glean lean: how to use lean approach in service industries?. Journal of Services Research, 6, 191-206.

Adeyemi, A., Martin, D., \& Kasim, R. (2017). The relevance of lean thinking to sustainable improvement of public office buildings in Nigeria. Journal of Engineering and Applied Sciences, 12(6), 1365-1376.

Albliwi, S. A., Antony, J., \& Lim, S. A. H. (2015). A systematic review of Lean Six Sigma for the manufacturing industry. Business Process Management Journal, 21(3), 665-691. https://doi.org/10.1108/BPMJ-03-2014-0019

Andersson, R., Hilletofth, P., Manfredsson, P., Hilmola, O. P. (2014). Lean Six Sigma strategy in telecom manufacturing. Industrial Management \& Data Systems, 114(6), 904-921. https://doi.org/10.1108/IMDS-02-2014-0069

Antony, J.; Escamilla, J. L.; Caine, P. (2003). Lean Sigma. Manufacturing Engineer, 82(2), 40-42. https://doi.org/10.1049/me:20030203

Antony, J. (2004). Six Sigma in the UK service organisations: results from a pilot survey. Managerial Auditing Journal, 19(8), 1006-1013. https://doi.org/10.1108/02686900410557908

Antony, J., Kumar, M., \& Cho, B. R. (2007). Six Sigma in service organizations: benefits, challenges, difficulties, common myths and success factors. International Journal of Quality \& Reliability Management, 24(2), 294-311. https://doi.org/10.1108/02656710710730889

Azevedo, S. G., Carvalho, H., Duarte, S., \& Cruz-Machado, V. (2012). Influence of green and lean upstream supply chain management practices on business sustainability. IEEE Transactions on Engineering Management, 59(4), 753-765. https://doi.org/10.1109/TEM.2012.2189108

Aziz, R. F., \& Hafez, S. M. (2013). Applying lean thinking in construction and performance improvement. Alexandria Engineering Journal, 52(4), 679-695.

Beasley, G., \& Rosseel, T. (2016). Leaning into sustainability at University of Alberta Libraries. Library Management, 37(3), 136-148. https://doi.org/10.1108/LM-04-2016-0023

Caiado, R. G. G., Dias, R. F., Mattos, L. V., Quelhas, O. L. G., \& Leal Filho, W. (2017). Towards sustainable development through the perspective of eco- efficiency - a systematic literature review. Journal of Cleaner Production, 165, 890-904. https://doi.org/10.1016/j.jclepro.2017.07.166

Camuffo, A., De Stefano, F., Paolino, C. (2017). Safety reloaded: lean operations and high involvement work practices for sustainable workplaces. Journal of Business Ethics, 245-259. https://doi.org/10.1007/s10551-015-2590-8

Cherrafi, A., Elfezazi, S., Chiarini, A., Mokhlis, A., \& Benhida, K. (2016). The integration of lean manufacturing, Six Sigma and sustainability: a literature review and future research directions for developing a specific model. Journal of Cleaner Production, 139, 828-846.

https://doi.org/10.1016/j.jclepro.2016.08.101 
Cherrafi, A., Elfezazi, S., Govindan, K., Garza-Reyes, J. A., Benhida, K., \& Mokhlis, A. (2017). A framework for the integration of Green and Lean Six Sigma for superior sustainability performance. International Journal of Production Research, (March), 1-35. https://doi.org/10.1080/00207543.2016.1266406

Chiarini, A. (2014). Sustainable manufacturing-greening processes using specific lean production tools: an empirical observation from European motorcycle component manufacturers. Journal of Cleaner Production, 85, 226-233. https://doi.org/10.1016/j.jclepro.2014.07.080

Chugani, N., Kumar, V., Garza-Reyes, J. A., Rocha-Lona, L., \& Upadhyay, A. (2017). Investigating the green impact of Lean, Six Sigma and Lean Six Sigma. International Journal of Lean Six Sigma, 8(1), 7-32. https://doi.org/10.1108/IJLSS-11-2015-0043

Comm, C. L., \& Mathaisel, D. F. X. (2005). A case study in applying lean sustainability concepts to universities. International Journal of Sustainability in Higher Education, 6(2), 134-146. https://doi.org/10.1108/14676370510589855

Comm, C. L., \& Mathaisel, D. F. X. (2003). Less is more: a framework for a sustainable university. International Journal of Sustainability in Higher Education, 4(4), 314-323. https://doi.org/10.1108/14676370310497543

Dhingra, R., Kress, R., \& Upreti, G. (2014). Does Lean mean Green? Journal of Cleaner Production, 85, 1-7. https://doi.org/10.1016/j.jclepro.2014.10.032

Duarte, S., \& Cruz-Machado, V. (2009). Modelling lean and green: a review from business models. International Journal of Lean Six Sigma, 4(3), 1-23. Retrieved from http://www.emeraldinsight. com/10.1108/IJLSS-05-2013-0030

Dües, C. M., Tan, K. H., \& Lim, M. (2013). Green as the new lean: how to use lean practices as a catalyst to greening your supply chain. Journal of Cleaner Production, 40, 93-100. https://doi.org/10.1016/j.jclepro.2011.12.023

Fercoq, A., Lamouri, S., \& Carbone, V. (2016). Lean/green integration focused on waste reduction techniques. Journal of Cleaner Production, 137, 567-578. https://doi.org/10.1016/j.jclepro.2016.07.107

Ferguson, D. (2007). Lean and six sigma: the same or different?. Management Services, 51(3), 12-13.

Folinas, D., Aidonis, D., Triantafillou, D., \& Malindretos, G. (2013). Exploring the greening of the food supply chain with lean thinking techniques. Procedia Technology, 8, 416-424. https://doi.org/10.1016/j.protcy.2013.11.054

Folinas, D., Aidonis, D., Malindretos, G., Voulgarakis, N., \& Triantafillou, D. (2014). Greening the agrifood supply chain with lean thinking practices. International Journal of Agricultural Resources, Governance and Ecology, 10(January), 129-145. https://doi.org/10.1504/IJARGE.2014.063580

Franchetti, M. J. (2015). Lean six sigma for engineers and managers: with applied case studies. CRC Press.

Furukawa, P. D. O., Cunha, I. C. K. O., \& Pedreira, M. D. L. G. (2016). Evaluation of environmentally sustainable actions in the medication process. Revista brasileira de enfermagem, 69(1), 23-29. https://doi.org/10.1590/0034-7167.2016690103i

Garza-Reyes, J. A. (2015a). Green lean and the need for Six Sigma. International Journal of Lean Six Sigma, 6(3), 226-248. https://doi.org/10.1108/IJLSS-04-2014-0010

Garza-Reyes, J. A. (2015b). Lean and green - a systematic review of the state of the art literature. Journal of Cleaner Production, 102, 18-29. https://doi.org/10.1016/j.jclepro.2015.04.064

George, M. L. (2002). Lean Six Sigma: combining Six Sigma quality with lean speed. McGraw-Hill, NewYork, NY.

George, M. L. (2003). Lean six sigma for service. New York, NY: McGraw-Hill.

Goffnett, S. P., Lepisto, L., \& Hayes, R. (2016). Using the socio-economic approach to management to augment Lean Six Sigma. International Journal of Productivity and Performance Management, 65(1), 80-97. https://doi.org/10.1108/IJPPM-02-2014-0028 
Gupta, S., Sharma, M., \& Sunder M. V. (2016). Lean services: a systematic review. International Journal of Productivity and Performance Management, 65(8), 1025-1056. https://doi.org/10.1108/IJPPM-02-2015-0032

Gutierrez-Gutierrez, L., de Leeuw, S., \& Dubbers, R. (2016). Logistics services and Lean Six Sigma implementation: a case study. International Journal of Lean Six Sigma, 7(3), 324-342. https://doi.org/10.1108/IJLSS-05-2015-0019

Haddach, A., Ammari, M., \& Laglaoui, A. (2016). Role of lean, environmental and social practices to increasing firm's overall performance. Journal of Materials and Environmental Science, 7(2).

Hallam, C., \& Contreras, C. (2016). Integrating lean and green management. Management Decision, 54(9), 2157-2187. https://doi.org/10.1108/MD-04-2016-0259

Hilton, R. J., \& Sohal, A. (2012). A conceptual model for the successful deployment of Lean Six Sigma. International Journal of Quality \& Reliability Management, 29(1), 54-70. https://doi.org/10.1108/02656711211190873

Jadhav, J. R., Mantha, S. S., \& Rane, S. B. (2014). Development of framework for sustainable lean implementation: an ISM approach. Journal of Industrial Engineering International, 10(3), 72. https://doi.org/10.1007/s40092-014-0072-8

Kumar, S., Luthra, S., Govindan, K., Kumar, N., \& Haleem, A. (2016). Barriers in green lean six sigma product development process: an ISM approach. Production Planning and Control, 27(7-8), 604-620. https://doi.org/10.1080/09537287.2016.1165307

Kurdve, M., Zackrisson, M., Wiktorsson, M., \& Harlin, U. (2014). Lean and green integration into production system models-experiences from Swedish industry. Journal of Cleaner Production, 85, 180-190. https://doi.org/10.1016/j.jclepro.2014.04.013

Laureani, A., \& Antony, J. (2012). Critical success factors for the effective implementation of Lean Sigma: results from an empirical study and agenda for future research. International Journal of Lean Six Sigma, 3(4), 274-283.

León, H. C. M., \& Calvo-Amodio, J. (2017). Towards lean for sustainability: understanding the interrelationships between lean and sustainability from a systems thinking perspective. Journal of Cleaner Production, 142, 4384-4402. https://doi.org/10.1016/j.jclepro.2016.11.132

Levitt, T. (1972). Production line approach to service. Harvard Business Review, 50(5), 32-43.

Lozano, R., Suzuki, M., Carpenter, A., \& Tyunina, O. (2017). An analysis of the contribution of Japanese business terms to corporate sustainability: learnings from the 'Looking-Glass' of the East. Sustainability, 1-17. https://doi.org/10.3390/su9020188

Lubowe, D., \& Blitz, A. (2008). Driving operational innovation using Lean Six Sigma. Business Performance Management, 6(3), 10-15.

Manville, G., Greatbanks, R., Krishnasamy, R., \& Parker, D. W. (2012). Critical success factors for Lean Six Sigma programmes: a view from middle management. International Journal of Quality \& Reliability Management, 29(1), 7-20. https://doi.org/10.1108/02656711211190846

Manzouri, M., Ab-Rahman, M. N., Zain, C. R. C. M., \& Jamsari, E. A. (2014). Increasing production and eliminating waste through lean tools and techniques for Halal food companies. Sustainability (Switzerland), 6(12). https://doi.org/10.3390/su6129179

Martínez León, H. C., \& Calvo-Amodio, J. (2017). Towards lean for sustainability: understanding the interrelationships between lean and sustainability from a systems thinking perspective. Journal of Cleaner Production, 142, 4384-4402. https://doi.org/10.1016/j.jclepro.2016.11.132

Nicoletti, B. (2013). Lean Six Sigma and digitize procurement. International Journal of Lean Six Sigma, 4(2), 184-203. https://doi.org/10.1108/20401461311319356

Parast, M. M. (2011). The effect of Six Sigma projects on innovation and firm performance. International Journal of Project Management, 29(1), 45-55. https://doi.org/10.1016/j.ijproman.2010.01.006 
Powell, D., Lundeby, S., Chabada, L., \& Dreyer, H. (2017). Lean Six Sigma and environmental sustainability: the case of a Norwegian dairy producer. International Journal of Lean Six Sigma, 8(1), 53-64. https://doi.org/10.1108/IJLSS-06-2015-0024

Popa, A., Ramos, R., Cover, A. B., \& Popa, C. G. (2005, January). Integration of artificial intelligence and lean sigma for large field production optimization: application to Kern River Field. SPE Annual Technical Conference and Exhibition. Society of Petroleum Engineers.

Psychogios, A. G., \& Tsironis, L. K. (2012). Towards an integrated framework for Lean Six Sigma application: lessons from the airline industry. Total Quality Management \& Business Excellence, 23(4), 397-415. https://doi.org/10.1080/14783363.2011.637787

Ranky, P. G., \& Kalaba, O. (2012). Sustainable lean six-sigma green engineering system design educational challenges and interactive multimedia solutions. 2012 IEEE International Symposium on Sustainable Systems and Technology (ISSST), IEEE (pp. 1-6). https://doi.org/10.1109/ISSST.2012.6227999

Ratnayake, R. M. C., \& Chaudry, O. (2017). Maintaining sustainable performance in operating petroleum assets via a lean-six-sigma approach. International Journal of Lean Six Sigma, 8(1), 33-52. https://doi.org/10.1108/IJLSS-11-2015-0042

Ray, S., \& John, B. (2011). Lean Six-Sigma application in business process outsourced organization. International Journal of Lean Six Sigma, 2(4), 371-380. https://doi.org/10.1108/20401461111189443

Ryerson, M. S., \& Kim, H. (2014). The impact of airline mergers and hub reorganization on aviation fuel consumption. Journal of Cleaner Production, 85, 395-407.

https://doi.org/10.1016/j.jclepro.2013.12.032

Saieg, P., Dominguez, E., Nascimento, D., \& Caiado, G. G. C. (2018). Interactions of building information modeling, lean and sustainability on the architectural, engineering and construction industry: a systematic review. Journal of Cleaner Production, 174, 788-806.

https://doi.org/10.1016/j.jclepro.2017.11.030

Suárez-Barraza, M. F., Smith, T., \& Dahlgaard-Park, S. M. (2012). Lean service: a literature analysis and classification. Total Quality Management \& Business Excellence, 23(3-4), 359-380. https://doi.org/10.1080/14783363.2011.637777

De Soete, W. (2016). Towards a multidisciplinary approach on creating value: sustainability through the supply chain and ERP Systems. Systems, 4(1), 16. https://doi.org/10.3390/systems4010016

Timans, W., Antony, J., Ahaus, K., \& van Solingen, R. (2012). Implementation of Lean Six Sigma in small-and medium-sized manufacturing enterprises in the Netherlands. Journal of the Operational Research Society, 63(3), 339-353. https://doi.org/10.1057/jors.2011.47

Tortorella, G. L., Vergara, L. G. L., \& Ferreira, E. P. (2017). Lean manufacturing implementation: an assessment method with regards to socio-technical and ergonomics practices adoption. International Journal of Advanced Manufacturing Technology, 89, 1-12. https://doi.org/10.1007/s00170-016-9227-7

Tsironis, L. K., \& Psychogios, A. (2016). Road towards Lean Six Sigma in service industry: a multifactor integrated framework. Business Process Management Journal, 22(4), 812-834. https://doi.org/10.1108/BPMJ-08-2015-0118

Ugarte, G. M., Golden, J. S., \& Dooley, K. J. (2016). Lean versus green: the impact of lean logistics on greenhouse gas emissions in consumer goods supply chains. Journal of Purchasing and Supply Management, 22(2). https://doi.org/10.1016/j.pursup.2015.09.002

Verrier, B., Rose, B., Caillaud, E., \& Remita, H. (2014). Combining organizational performance with sustainable development issues: the lean and green project benchmarking repository. Journal of Cleaner Production, 85, 83-93. https://doi.org/10.1016/j.jclepro.2013.12.023

Vijaya Sunder, M. (2016). Rejects reduction in a retail bank using Lean Six Sigma. Production Planning \& Control, 27(14), 1131-1142. https://doi.org/10.1080/09537287.2016.1187312 
Wang, F. K., \& Chen, K. S. (2012). Application of Lean Six Sigma to a panel equipment manufacturer. Total Quality Management \& Business Excellence, 23(3-4), 417-429. https://doi.org/10.1080/14783363.2011.593876

Wei, C. C., Sheen, G. J., Tai, C. T., \& Lee, K. L. (2010). Using Six Sigma to improve replenishment process in a direct selling company. Supply Chain Management: An International Journal, 15(1), 3-9. https://doi.org/10.1108/13598541011018076

Wiese, A., Luke, R., Heyns, G. J., \& Pisa, N. M. (2015). The integration of lean, green and best practice business principles. Journal of Transport and Supply Chain Management, 9(1), 1-10. https://doi.org/10.4102/jtscm.v9i1.192

Wong, W. P., \& Wong, K. Y. (2014). Synergizing an ecosphere of lean for sustainable operations. Journal of Cleaner Production, 85, 51-66. https://doi.org/10.1016/j.jclepro.2014.05.093

Zhan, Y., Tan, K. H., Ji, G., Chung, L., \& Chiu, A. S. F. (2015). Green and lean sustainable development path in China: Guanxi, practices and performance. Resources, Conservation and Recycling, 128, 240-249. https://doi.org/10.1016/j.resconrec.2016.02.006 